\title{
Availability of manganese from different manganese oxides and their effect on performance of broiler chickens
}

\author{
W. Korol ${ }^{1}$, S. Wójcik ${ }^{1}$, S. Matyka ${ }^{1}$ and T.S. Hansen ${ }^{2}$ \\ ' Central Laboratory of Feed Industry' \\ P.O. Box 143, 20-079 Lublin, Poland \\ ${ }^{2}$ Elkem Materials, \\ P.O.Box 8126, Vaagsbygd, N-4602 Kristiansand, Norway
}

(Received 3 April 1996; accepted 9 July 1996)

\begin{abstract}
An experiment was conducted to investigate the influence of manganese $(\mathrm{Mn})$ oxide added to mixed feeds on the performance of broiler chickens and Mn retention in the tibia bone. Six hundred broiler chickens were divided into 5 groups, and fed on maize-based diets without suppiemental $\mathrm{Mn}$ (group I) or with a supplement of $50 \mathrm{mg} / \mathrm{kg} \mathrm{Mn}$ as sulphate (group II) or 3 different feed grade manganese oxides (groups III, IV, V).

The greatest mean body weight of $2146 \mathrm{~g}$ was found in group II. Mean body wcights in the other groups were from 4.3 to $2.7 \%$ lower $(\mathrm{P}<0.05)$. Body weights and feed conversion rates of chickens fed diets supplemented with Mn oxides were similar to control birds fed a diet without supplemental Mn. Chickens of group II utilized mixed feeds most effectively $(\mathrm{P}<0.01)$.

Addition of $\mathrm{Mn}$ to diets at a level of $50 \mathrm{mg} / \mathrm{kg}$ as sulphate or oxides resulted in a tendency to increase the $\mathrm{Mn}$ concentration in the tibia of broiler chickens. $\mathrm{Mn}$ availability from the investigated manganesc oxides ranged from 61 to $74 \%$ and was lower than that from the sulphate, taken as $100 \%$.
\end{abstract}

KEY WORDS: manganese oxide, manganese retention, broiler chicken

\section{INTRODUCTION}

Manganese $(\mathrm{Mn})$ is an essential element in animal nutrition. Its deficiency in young birds, especially chickens and turkeys, results in perosis and slipped tendon; in laying and breeding birds it leads to lowered egg production, reduced egg shell strength, poor hatchability and reduced fertility (NRC, 1994). 
The $\mathrm{Mn}$ requirement in broiler chickens according to NRC (1994) is $60 \mathrm{mg} / \mathrm{kg}$ of diet. Raw materials commonly used in broiler diets contain low amounts of $\mathrm{Mn}$ : maize (5 mg/ $/ \mathrm{kg})$, wheat $(26 \mathrm{mg} / \mathrm{kg}$ ), soyabean meal ( $38 \mathrm{mg} / \mathrm{kg}$ ) (Nutrient Requirements of Poultry, 1993). Furthermore, the bioavailability of Mn from cereals and oil meals is $50-70 \%$. In order to increase the $\mathrm{Mn}$ content in broiler diets, salts of this element, especially $\mathrm{Mn}$ sulphate, are added as a supplement at a level of $50 \mathrm{mg} / \mathrm{kg}$. In addition to $\mathrm{Mn}$ sulphate, $\mathrm{Mn}$ oxides in the form of fine-grained powders, which are easier to mix, are often used.

$\mathrm{Mn}$ as a sulphate or chloride is more available than carbonate or oxide (Black et al., 1984). But these investigations on Mn availability were conducted at high levels of this element, from 1000 to $4000 \mathrm{mg} / \mathrm{kg}$, not used in animal nutrition. In availability research, high doses of $\mathrm{Mn}$ could be questioned because a non-linear increase in the tissue content of this element was found as the $\mathrm{Mn}$ level in feed rose (Henry et al., 1986). Moreover, a high level of $\mathrm{Mn}$ in the diet can reduce absorption of other elements.

The following experiment was conducted to study the influence of Mn oxides added at near requirement levels to mixed feeds on the performance of chickens and $\mathrm{Mn}$ retention in their tibias.

\section{MATERIAL AND METHODS}

The experiment was performed on 600 Shaver Minibro sexed broiler chickens reared to 42 days. The birds were divided into 5 groups. Treatment groups were replicated six times ( 20 birds in each replication - 10 males and 10 females).

The birds were kept in thermostatically controlled and electrically heated batteries placed in an air-conditioned room and were allowed ad libitum access to feed and water. For the first 3 weeks broilers were fed on starter, from 4 to 6 weeks on grower diets (Table 1). Broilers of the control group were fed on the basal diets without Mn supplementation (Treatment I) or with the addition of 50 $\mathrm{mg} \mathrm{Mn} / \mathrm{kg}$ of feed as sulphate (Treatment II). Birds of the experimental groups were fed the same basal diet with different Mn oxide preparations: Agrimax P-70 (Treatment III) and Agrimax S-68 (Treatment IV) supplied by Elkem Materials (Norwey) and reference feed grade (FG) Mn oxide (Treatment V).

The main constituent of the Elkem product, Agrimax, is $\mathrm{Mn}_{3} \mathrm{O}_{4}$. Both Agrimax preparations contain $31 \% \mathrm{MnO}$ and $69 \% \mathrm{Mn}_{2} \mathrm{O}_{3}$. The reference $\mathrm{Mn}$ oxide supplied by Elkem is made by Sedema: Alma feed grade, Belgium. Mn oxides were added in an amount to supply $50 \mathrm{mg} \mathrm{Mn} / \mathrm{kg}$ of feed. The content of $\mathrm{Mn}$ in oxide preparations is presented in Table 2.

During the experiment, bird health and mortality were constantly monitored. After 3 and 6 weeks chick body weight and feed consumption were recorded and feed conversion calculated. 
TABLE 1

Composition of basal diets, $\%$

\begin{tabular}{|c|c|c|}
\hline \multirow[t]{2}{*}{ Indices } & \multicolumn{2}{|c|}{ Diets } \\
\hline & starter & grower \\
\hline Maize & 54.23 & 15.99 \\
\hline Wheat & - & 53.68 \\
\hline Wheat bran & 0.66 & - \\
\hline Soyabean oilmeal & 33.60 & 17.29 \\
\hline Meat meal & 3.00 & 6.00 \\
\hline Rapeseed oil & 4.86 & 4.80 \\
\hline Limestone & 0.54 & 0.60 \\
\hline Dicalcium phosphate & 1.34 & 0.63 \\
\hline Premix L-Lysine $50 \%$ & 0.54 & 0.15 \\
\hline Premix DL-Methionine $50 \%$ & 0.32 & 0.26 \\
\hline $\mathrm{NaCl}$ & 0.41 & 0.10 \\
\hline Mineral-vitamin premix* & 0.50 & 0.50 \\
\hline Calculated $\mathrm{AME}_{\mathrm{N}}, \mathrm{kcal} / \mathrm{kg}$ & 3040 & 3080 \\
\hline \multicolumn{3}{|l|}{ Chemical analysis, $\mathrm{g} / \mathrm{kg}$} \\
\hline dry matter & 884 & 886 \\
\hline ash & 64 & 48 \\
\hline crude protein & 221 & 190 \\
\hline ether extract & 70 & 64 \\
\hline crude fibre & 31 & 28 \\
\hline
\end{tabular}

* Premix provides per kilogram of diet: vitamin A, 12000 IU; vitamin $\mathrm{D}_{3}, 3000 \mathrm{IU}$; vitamin $\mathrm{E}, 20 \mathrm{mg}$; vitamin $\mathrm{K}, 3 \mathrm{mg}$; vitamin $\mathrm{B}_{1}, 2 \mathrm{mg}$; vitamin $B_{2}, 6 \mathrm{mg}$; vitamin $B_{6}, 2 \mathrm{mg}$; vitamin $B_{12}, 15 \mathrm{ug}$; biotin, $0.05 \mathrm{mg}$; folic acid, $1.0 \mathrm{mg}$; niacin, $20 \mathrm{mg}$; calcium pantothenate, $12 \mathrm{mg}$; choline, $200 \mathrm{mg}$; dl-methionine, $1 \mathrm{~g}$; manganese, $0.0 \mathrm{mg}$; zinc, $50 \mathrm{mg}$; copper, $6 \mathrm{mg}$; iron, $20 \mathrm{mg}$; iodine, $0.5 \mathrm{mg}$; selenium, $0.1 \mathrm{mg}$; cobalt, $0.2 \mathrm{mg}$

TABLE 2

Manganese concentration and heavy metal residue in preparations

\begin{tabular}{lccc}
\hline Indices & $\begin{array}{c}\mathrm{Mn} \\
\%\end{array}$ & $\begin{array}{c}\mathrm{Cd} \\
\mathrm{mg} / \mathrm{kg}\end{array}$ & $\begin{array}{c}\mathrm{Pb} \\
\mathrm{mg} / \mathrm{kg}\end{array}$ \\
\hline Manganese sulphate & 31.7 & 8 & 17 \\
Agrimax P-70 $\mathrm{MnO} \cdot \mathrm{Mn}_{2} \mathrm{O}_{3}$ & 70.1 & 3 & 320 \\
Agrimax S-68 MnO $\cdot \mathrm{Mn}_{2} \mathrm{O}_{3}$ & 68.9 & 4 & 928 \\
Reference feed grade $\mathrm{Mn}$ oxide & 62.0 & 8 & 140 \\
\hline
\end{tabular}


At the end of the experiment 6 chickens from each treatment $(3$ males and 3 females) were killed, the tibias were excised, cleaned and kept frozen in plastic bags for $\mathrm{Mn}$ analysis. After ashing the tibia at $550^{\circ} \mathrm{C}$ and digesting the ash, the resulting solutions were analyzed for $\mathrm{Mn}$ using atomic absorption spectrometry (Unicam, Model 9100 X). The same method was used for determination of Mn in mixed feeds and $\mathrm{Cd}$ as well as $\mathrm{Pb}$ in preparations. The $\mathrm{Mn}$ content in preparations was analyzed by potentiometric titration. Basal nutrients in mixed feeds were determined by conventional methods.

The data were submitted to analysis of variance and the differences between means were determined by Duncan's multiple range test.

\section{RESULTS AND DISCUSSION}

Treatment diets and chemical composition of mixed feeds are shown in Tables 1 and 2. Protein, fibre and metabolizable energy contents corresponded with the requirements of Nutrient Requirements of Poultry (1993). Differences between treatments resulted from $\mathrm{Mn}$ supplementation and type of $\mathrm{Mn}$ compound. The difference in $\mathrm{Mn}$ levels for Treatments II - V was in the range of acceptable deviation.

The Mn content of the studied preparations (Table 2) was 1.1 to $3.4 \%$ lower than the declared levels, which is in the range of permissible deviation. Heavy metal contents varied. The Cd concentration was low, from 3 to $8 \mathrm{mg} / \mathrm{kg}$, and did not create a risk of toxic residue in animal products. The $\mathrm{Pb}$ concentration was highest in the Agrimax S-68 preparation and amounted to $928 \mathrm{mg} / \mathrm{kg}$. Although Agrimax S-68 contained a higher level of $\mathrm{Pb}$ than the other preparations, the use of this source at the recommended dietary level of $50 \mathrm{mg} \mathrm{Mn} / \mathrm{kg}$ would contribute only $0.071 \mathrm{mg} \mathrm{Pb} / \mathrm{kg}$ of the mixed feed. This amount is much below the maximal tolerable level in poultry mixed feeds, i.e. $10 \mathrm{mg} \mathrm{Pb} / \mathrm{kg}$ (Feeding Stuffs Regulations, Agriculture No 386, 1988; Wong-Valle et al., 1989).

The performance of broiler chickens is presented in Table 3 . There were no differences in body weight (from 672 to $693 \mathrm{~g}$ ) of 3-week chickens due to treatments. After 6 weeks the average chicken body weight amounted to $2096 \mathrm{~g}$. The highest body weight, $2146 \mathrm{~g}$, was found in Treatment II in which broiler chickens were fed mixed feed supplemented with $\mathrm{Mn}$ sulphate. The mean body weight was lower in the remaining treatments, from 4.3 to $2.7 \%(\mathrm{P}<0.05)$.

The final body weight of chickens in the control Treatment I did not significantly differ from that found in Treatments III-V. This data corresponds with the findings of Kirchgessner et al. (1989), who observed that $\mathrm{Mn}$ supplementation of diets at levels from 8 to $60 \mathrm{mg} / \mathrm{kg}$ did not influence body weight gain, feed conversion or mortality of birds. 
TABLE 3

Live body weight (LBW), fecd conversion ratio (FCR) and mortality

\begin{tabular}{lcccccc}
\hline Indices & \multicolumn{7}{c}{ Treatment } \\
\cline { 2 - 8 } & I & II & III & IV & V & SEM \\
\hline LBW, g: & & & & & & \\
$\quad-3$ week & 693 & 695 & 685 & 672 & 689 & 24.08 \\
- 6 weck & $2108^{\mathrm{ab}}$ & $2146^{\mathrm{a}}$ & $2053^{\mathrm{b}}$ & $2085^{\mathrm{b}}$ & $2089^{\mathrm{b}}$ & 35.77 \\
FCR, kg/kg: & & & & & & \\
-3 week & 1.57 & 1.55 & 1.56 & 1.70 & 1.63 & 0.104 \\
-6 week & $2.18^{\mathrm{AB}}$ & $2.11^{\mathrm{A}}$ & $2.38^{\mathrm{b}}$ & $2.41^{\mathrm{B}}$ & $2.40^{\mathrm{B}}$ & 0.093 \\
Mortality, \% & 5.8 & 0.8 & 4.2 & 8.3 & 6.7 & 4.16 \\
\hline
\end{tabular}

$a, b-P<0.05$

$\mathrm{A}, \mathrm{B}-\mathrm{P}<0.01$

Feed conversion in all periods resulted from the rate of bird growth. Chickens from Treatment II utilized mixed feeds most effectively $(\mathrm{P}<0.01)$. Among others, better feed conversion in this treatment was the effect of low mortality $(0.8 \%)$. Protein conversion was similar to feed conversion and was lowest in Treatment II in which broiler chickens were fed on mixed feed with supplemental Mn sulphate.

Mean mortality of broiler chickens in the experiment amounted to $5.2 \%$. Leg abnormalities were not recorded.

The $\mathrm{Mn}$ concentration in the tibia bone of broiler chickens averaged $7.08 \mathrm{mg} / \mathrm{kg}$, with no significant differences. However, a tendency for the $\mathrm{Mn}$ concentration to increase above the value for group I in $\mathbf{M n}$ - supplemented groups II-V was observed. On the basis of differences in Mn concentration of control group I and the remaining groups, it was assumed that $\mathrm{Mn}$ availability from sulphate equaled $100 \%$, and the relative bioavailability of $\mathrm{Mn}$ from the investigated oxides was calculated. Mn availability from Agrimax P-70, Agrimax S-68 and reference FG Mn oxide preparations was 74,61 and $72 \%$, respectively (Table 4).

The availability of $\mathrm{Mn}$ from Agrimax preparations determined in this experiment was similar to that from reference FG Mn oxide. Black et al.(1984) found that the availability of $\mathrm{Mn}$ from $\mathrm{MnO}$, calculated on the basis of $\mathrm{Mn}$ retention in chicken bone, was about $60 \%$. Mn availability from sulphate was double that from the carbonate salt. Wong-Valle et al. (1989) noted that the bioavailability of $\mathrm{Mn}$ from oxides of different origin, determined in the same manner, equaled 70 to $93 \%$ of Mn bioavailability from sulphate salt. Black et al. (1984) and Wong-Valle et al. (1989) investigated Mn availability at high levels of $\mathrm{Mn}$ oxide supplementation, from 1000 to $4000 \mathrm{mg} / \mathrm{kg}$. However, Henry et al. 
TABLE 4

Manganese concentration in mixed feed and tibia bones of broiler chickens and relative bioavailability of manganese

\begin{tabular}{|c|c|c|c|c|c|c|}
\hline \multirow[t]{2}{*}{ Indices } & \multicolumn{6}{|c|}{ Manganese preparation addcd } \\
\hline & $\begin{array}{c}\text { I } \\
\text { no added }\end{array}$ & $\begin{array}{c}\text { II } \\
\text { sulphate }\end{array}$ & $\begin{array}{c}\text { III } \\
\text { oxide } \\
\text { Agrimax } \\
\text { P-70 }\end{array}$ & $\begin{array}{c}\text { IV } \\
\text { oxide } \\
\text { Agrimax } \\
\text { S-68 }\end{array}$ & $\begin{array}{c}V \\
\text { Ref. FG } \\
\text { Mn } \\
\text { oxide }\end{array}$ & SEM \\
\hline \multicolumn{7}{|l|}{$\mathrm{Mn}$ in diet, $\mathrm{mg} / \mathrm{kg}$} \\
\hline - starter & 53 & 102 & 99 & 105 & 106 & - \\
\hline - grower & 40 & 99 & 90 & 88 & 87 & - \\
\hline Mn in tibia ash, $\mathrm{mg} / \mathrm{kg}$ & 6.62 & 7.38 & 7.18 & 7.08 & 7.17 & 1.243 \\
\hline $\begin{array}{c}\mathrm{Mn} \text { in tibia bone, } \\
\mathrm{mg} / \mathrm{kg} \mathrm{DM}\end{array}$ & 2.98 & 3.25 & 3.19 & 3.15 & 3.19 & 0.554 \\
\hline Relative bioavailability, $\%$ & - & 100 & 74 & 61 & 72 & - \\
\hline
\end{tabular}

(1986) obtained similar availability of $\mathrm{Mn}$ from oxides, equal to $66 \%$, at $\mathrm{Mn}$ supplementation from 40 to $120 \mathrm{mg} / \mathrm{kg}$, comparable to that used in this experiment.

\section{CONCLUSIONS}

The addition of $\mathrm{Mn}$ to diets at a level of $50 \mathrm{mg} / \mathrm{kg}$ of feed as exides resulted in a tendency to increase the Mn concentration in the tibia of broiler chickens. Chickens fed diets with supplemental Mn oxides attained body weights and feed conversion similar to control birds fed diets without supplemental Mn. Chickens from group with supplemental Mn sulpfate attained favourable performance parameters. The results of the retention study indicated that the availability of $\mathrm{Mn}$ from $\mathrm{MnO} \cdot \mathrm{Mn}_{2} \mathrm{O}_{3}$ was comparable to availability from reference $\mathrm{FG} \mathrm{Mn}$ oxide.

\section{REFERENCES}

Black J.R., Ammerman C.B., Henry P.R., Miles R.D., 1984. Biological availability of manganese sources and cffects of high dietary manganese on tissue mineral composition of broiler-type chicks. Poultry Sci. 63, 1999-2006

Henry P.R., Ammerman C.B., Miles R.D., 1986. Bioavailability of manganese sulfate and manganese monoxide in chicks as measured by tissue uplake of manganese from conventional dietary levels. Poultry Sci. 65, 983-986 
Kirchgessner M., Weigand E., Kilic A., 1989. Einfluss einer abgestuften Mangen-und Calziumzufuhr aul Wachstum, Futterverwertung und Mortalitat von Broilern. Arch. Geflügelk. 53, (5), 191-198

National Rescarch Council, 1994. Nutrient Requirements of Poultry. 9th ed. National Academy Press, Washington, D.C.

Nutrient Requirements of Poultry. Nutritive value of feeds (in Polish), 1993. IInd ed. The Kielanowski Institute of Animal Physiology and Nutrition (Editor), Jablonna, pp. 1-9]

Wong-Valle J., Ammerman C.B., Henry P.R., Rao P.V., Miles R.D., 1989. Bioavailability of manganese from feed grade manganese oxides for broiler chicks. Poultry Sci. 68, 1368-1373

\section{STRESZCZENIE}

\section{Dostępność manganu z różnych tlenków manganu i ich wplyw na wyniki odchowu kurčąt}

W doświadcreniu badano wplyw tlenków manganu (Mn) dodanych do mieszanek paszowych na wyniki odchowu i retencję Mn w kości piszczclowcj kurcząt brojlcrów. Sześćset brojlerów podzielonych na 5 grup żywiono natłuszczonymi mieszankami paszowymi z udziałem kukurydzy, pszenicy i śruty sojowej bez dodatku Mn (I) lub z dodatkiem $50 \mathrm{mg} \mathrm{Mn} / \mathrm{kg}$ paszy w postaci siarczanu (II), preparatów zawierających mieszaninę tlenków $\mathrm{MnO}: \mathrm{Mn}_{2} \mathrm{O}_{3}$ (Agrimax P-70; III), (Agrimax S-68; IV) i paszowego tlenku Mn (V).

Największą masę ciała, równą $2146 \mathrm{~g}$, osiągnçly kurczęta z grupy II. Masa ciała kurcząt w pozostałych grupach była niższa o 4,3 do $2,7 \%(P<0,05)$. Masa ciała i wykorzystanie paszy pr ptaki żywione mieszankami z dodatkiem llenków były podobne jak ptaków z grupy kontrolnej, żywionych paszą bez dodatku Mn. Kurc/çta z grupy II lepiej wykorzystywaly paszę niż kurczęta z grup IV i V $(P<0,01)$.

Przy dodatku Mn w postaci siarczanu lub tlenków wystąpiła tendencja zwiększenia odkładania Mn w kości piszczelowej ptaków. Przy przyjęciu przyswajalności Mn 7. siarczanu za 100\%, przyswajalność Mn z preparatu Agrimax S-68 wyniosła 61, paszowego tlenku Mn - 72, a Agrimax P-70 - 74\%. 